\title{
Preliminary use of cashew kernel oil in Clarias gariepinus fingerlings diet: comparison with fish oil and palm oil
}

\author{
Morgane Paul Magouana Anvo - Rokyatou Sissao - Benié Rose Danielle Aboua • \\ Chantal Yvette Zoungrana-Kaboré • Athanase Kraidy Otchoumou • \\ Essetchi Paul Kouamelan · Aboubacar Toguyéni
}

Received: 23 November 2016/ Accepted: 29 March 2017/Published online: 5 April 2017

(C) The Author(s) 2017. This article is an open access publication

\begin{abstract}
The present study was performed to investigate the effect of fish oil (FO), palm oil (PO), and cashew kernel oil (CKO) as the dietary lipid sources on the growth performance, tissues fatty acids composition and economical profitability in Clarias gariepinus fingerlings. Three isonitrogenous (49.32\%), isolipidic $(15.18 \%)$, and isoenergetic $(21 \mathrm{~kJ} / \mathrm{g})$ diets were formulated, differed only to the added lipid source and coded accordingly as D1 (fish oil), D2 (palm oil), and D3 (cashew kernel oil). Catfish fingerlings (initial body weight $=2.43 \pm 0.04 \mathrm{~g}$ ) were stocked at $1 \mathrm{fish} / \mathrm{L}$ and fed to trial diets at $5.6 \%$. At the end of 8 weeks, C. gariepinus fingerlings fed with D1 and D3 had significantly identical growth and feed utilization efficiency. Those fed with D2 exhibited significantly and numerically low growth performance compared, respectively, to D1 and D3. Contrary to whole-body composition of fish, the muscle lipids fatty acids composition was influenced by the fatty acids profile of the dietary lipid sources. High net profit value (NPV) of $24.59 \$$, high investment cost analysis (ICA) of $10.14 \$$ and low benefit: cost ratio (BCR) of 2.42 were observed in fish fed with D1 while those fed with D3 allowed to have high NPV (23.15\$), low ICA (7.86\$) and high BCR (2.95). Like others vegetable oils, cashew kernel oil can replace expensive fish oil in C. gariepinus fingerlings diet without negatively affecting its growth performances.
\end{abstract}

Keywords Clarias gariepinus · Vegetable oils · Fish oil · Growth performance

\section{Introduction}

The supply of fish products of Burkina Faso in 2009 was 56,400 tons, including 12,000 tons from domestic production with only 400 tons produced by aquaculture, and 44,400 tons come from import (Kabré et al. 2014). Given the importance of a river system, fish farming is a promising alternative to reduce the

M. P. M. Anvo $(\bowtie)$ · B. R. D. Aboua · E. P. Kouamelan

Laboratoire d'Hydrobiologie et d'Eco-technologie des eaux, UFR. Biosciences, Université Félix Houphouët-Boigny,

22 BP 582, Abidjan 22, Côte d'Ivoire

e-mail: morgane1er@yahoo.fr

M. P. M. Anvo · R. Sissao · C. Y. Zoungrana-Kaboré · A. Toguyéni

Unité de Recherche en Aquaculture et Biodiversité Aquatique/Laboratoire d'Etude et de Recherche sur les Ressources

Naturelles et Sciences de l'Environnement (UR-ABAQ/LERNSE), Université Polytechnique de Bobo-Dioulasso,

01 BP 1091, Bobo-Dioulasso 01, Burkina Faso

A. K. Otchoumou

Laboratoire de biotechnologie, UFR Biosciences, Université Félix Houphouët-Boigny, 22 BP 582, Abidjan 22, Côte d'Ivoire 
dependence of this country on the importation of fish. Especially since the per capita fish consumption has increased regularly from $1.5 \mathrm{~kg} / \mathrm{year}$ in 2003 (Kabré et al. 2014) to more than $5 \mathrm{~kg} / \mathrm{year}$ in 2013 (FAO 2016).

Aquaculture production in the developing countries is greatly constrained by undersupply, scarcity and high cost of conventional fish feed (Fagbenro and Arowosegbe 1991). Moreover, fish feed alone account for between 60 and $75 \%$ of the total cost of fish production (Babalola 2010). Thus, aquaculture production can be profitable only if the operators have access to balanced food at competitive prices (FAO 2016) by using locally available inputs.

Fish oil is a main dietary lipid source used in commercial aquafeeds. Other than providing a source of energy and essential fatty acids, it is commonly used to coat the extruded pellets in order to improve the palatability and appearance of the feed ( $\mathrm{Ng}$ and Chong 2004). According to Riediger et al. (2009), fish oils are particularly rich in the longer chain omega-3 fatty acids such as eicosapentaenoic acid (EPA) and docosahexaenoic acid (DHA) which are highly desirable in fish and human nutrition, although they are absent in most of vegetable oils (Montero et al. 2007).

However, the stagnation in global fish oil production coupled with increased demand for its use in aquaculture feeds (Barlow 2000) caused its price inflation. This situation led to several researches directed towards the evaluation of less expensive lipid sources to replace partially or totally fish oil. Vegetable oils have been found as potential substitutes for fish oil in fish diets. Numerous studies have shown that vegetable oils can substitute fish oil in fish diets without affecting fish growth. Indeed, palm oil ( $\mathrm{Ng}$ et al. 2003; Yilmaz et al. 2004; Nyina-wamwiza et al. 2007; Sotolu 2010; Effiong and Akpan 2016), sunflower oil (Ng et al. 2003; Nyina-wamwiza et al. 2007; Effiong and Akpan 2016), soya oil (Sotolu 2010), coconut oil (Aderolu and Akinremi 2009; Hammed et al. 2014; Effiong and Akpan 2016), groundnut oil (Sotolu 2010), shea butter oil (Aderolu et al. 2011), and olive and sesame oil (Effiong and Akpan 2016) have successfully been used in Clarias gariepinus diet. Nevertheless, they are not always available and become some time expensive. For example, palm oil which is the second most used oil in aquafeeds is costly in Burkina Faso where the palm trees do not grow. Thus, there is the need to investigate other lipid sources in fish diets.

Anacardium occidentale (cashew) belongs to Anacardiaceae family and is native to north eastern of Brazil. The first plantations were introduced around 1960 by the Tropical Forest Technical Center in Burkina Faso (Bila et al. 2010). This country has an annual production of about 75,000 metric tons of raw cashew nuts (Rabany et al. 2015). Two oils are obtained from its nuts. The first found between the seed coat or pericarp and the nuts, called the cashew nut shell liquid (CNSL), is not suitable for consumption. The second type of oil found in the kernel of the cashew nut, called cashew kernel oil (CKO) is comparable to others vegetable oils (Idah et al. 2014) and is cheaper.

The African catfish C. gariepinus is a very popular aquaculture species in a number of African countries. It has been introduced in many countries of Europe and Asia due to its tolerance to drastic rearing conditions (wide range of temperatures, low oxygen and high salinity levels), high nutritive value, good taste, and few bones of this species. In addition, it has high fecundity and growth rate (Hecht et al. 1996). It is regarded as an opportunistic, omnivorous predator since $C$. gariepinus has the ability to efficiently utilize and/or switch between alternative foods sources such as plants and detritus when animals prey become scarce (Potts et al. 2008). Thus, it can feed on wide variety of ingredients of animal and plant origin.

Considering the less expansive price and high availability of cashew kernel oil in Burkina Faso, this oil could be used as an alternative dietary lipid source in C. gariepinus feeding in order to reduce the fish production cost in this country where fisheries produce only one-third of the population fish consumption. Thus, the aim of this study was to evaluate the nutritive potential of cashew kernel oil in C. gariepinus fingerlings diet in comparison to palm oil and conventional fish oil.

\section{Methods}

Fish and system

Clarias gariepinus fingerlings were obtained from the Study of Natural's Resources and Environment Sciences Laboratory, Unit of Aquaculture Research and Aquatic's Biodiversity of Polytechnic University of Bobo-Dioulasso, Burkina Faso. C. gariepinus fingerlings (initial weight: $2.43 \pm 0.04 \mathrm{~g}$ ) were separated into 
three lots according to experimental diets with three replicates. These fingerlings from the same batch were randomly distributed in each aquarium. Fish were stocked at 1 fingerling/L in $50 \mathrm{~L}$ aquarium. This density was maintained constant until the end of the experiment. Aquaria were connected to a recirculation system with mechanical filter. Its capacity was 500 L. Sponge, ceramic ring and foam was used as filtration materials. Water flow through each aquarium was maintained constant at $0.5 \mathrm{~L} / \mathrm{min}$. Water parameters such as dissolved oxygen, $\mathrm{pH}$, conductivity and temperature were measured each day at $8 \mathrm{AM}$ with multi-meter (HACH, HQ40D). Average values for water quality parameter monitored in the aquarium during the experiment were: $\mathrm{pH}, 6.77 \pm 0.28$; temperature, $29.01 \pm 1.22{ }^{\circ} \mathrm{C}$; dissolved oxygen, $4.22 \pm 0.32 \mathrm{mg} / \mathrm{L}$; and conductivity, $17.03 \pm 1.41 \mu \mathrm{S} / \mathrm{cm}$. To quantify the exact feed intake, the left-over of feed was siphoned out immediately, dried, and weighed. Each morning before feeding, feces were collected (siphoning). Fish sample were taken at the beginning and at the end of the experiment from each aquarium, sacrificed for whole-body composition and muscle lipids fatty acids analysis. At the end of the trial period, livers and viscera were removed from three other fish in each aquarium and weighed for the estimation of the hepatosomatic index (HSI) and the viscerosomatic index (VSI).

Experimental diets and feeding

Three isonitrogenous (49.32\%), isolipidic (15.08\%) and isoenergetic $(21 \mathrm{~kJ} / \mathrm{g})$ experimental diets, differing only in the added lipid source and coded D1 (fish oil), D2 (palm oil) and D3 (cashew nut oil) were formulated (Table 1). Each diet was manufactured by mixing all ingredients (including corresponding oil) with $20 \%$ of water. Floating pellets $(1.8 \mathrm{~mm})$ were obtained from the mixture using fish feed extruder (BEDO machine, BD-GP70), dried in an oven at $40{ }^{\circ} \mathrm{C}$ for $72 \mathrm{~h}$, and stored at $18{ }^{\circ} \mathrm{C}$ until their use in fish feeding. Fish were fed

Table 1 Formulation, cost and proximate composition of the experimental diets (g/100 g dry matter)

\begin{tabular}{|c|c|c|c|c|}
\hline Ingredients (\%) & D1 & D2 & D3 & Ingredient cost $(\$ / \mathrm{kg})$ \\
\hline Fish meal & 60.00 & 60.00 & 60.00 & 5.54 \\
\hline Soybean meal & 16.00 & 16.00 & 16.00 & 0.57 \\
\hline Maize meal & 13.00 & 13.00 & 13.00 & 0.24 \\
\hline Fish oil (Menhaden) & 6.00 & 0.00 & 0.00 & 16.30 \\
\hline Palm oil & 0.00 & 6.00 & 0.00 & 1.95 \\
\hline Cashew kernel oil & 0.00 & 0.00 & 6.00 & 0.81 \\
\hline Lysine & 1.00 & 1.00 & 1.00 & 4.08 \\
\hline Methionine & 1.00 & 1.00 & 1.00 & 7.99 \\
\hline Vitamins mixture $^{\mathrm{a}}$ & 1.00 & 1.00 & 1.00 & 2.45 \\
\hline Minerals mixture $^{\mathrm{b}}$ & 1.00 & 1.00 & 1.00 & 1.31 \\
\hline Betaine & 1.00 & 1.00 & 1.00 & 8.15 \\
\hline Diet cost $(\$ / \mathrm{kg})$ & 4.67 & 3.79 & 3.73 & \\
\hline \multicolumn{5}{|c|}{ Proximate composition } \\
\hline Moisture & 9.19 & 8.98 & 9.26 & \\
\hline Crude protein & 48.98 & 49.37 & 49.62 & \\
\hline Crude lipid & 15.09 & 15.24 & 14.93 & \\
\hline Ash & 12.35 & 11.98 & 12.18 & \\
\hline Crude fiber & 3.45 & 3.79 & 3.73 & \\
\hline NFE & 20.13 & 19.62 & 19.54 & \\
\hline Energy $(\mathrm{kJ} / \mathrm{g})$ & 21.03 & 21.09 & 21.01 & \\
\hline
\end{tabular}

NFE: nitrogen-free extract $=100-($ crude protein + crude lipid + crude fiber + ash $)$

${ }^{a}$ Vitamins mixture: vit A: 2,500,000 IU; vit D3: 500,000 IU; vit E: 30,000 mg; vit K3: $2000 \mathrm{mg}$; vit B1: $2000 \mathrm{mg}$; vit B2: $5000 \mathrm{mg}$; panthotenic acid: 10,000 mg; niacin $5000 \mathrm{mg}$; vit B6: $4000 \mathrm{mg}$; folic acid: $2000 \mathrm{mg}$; vit B12: $80 \mathrm{mg}$; vit C: 20,000 mg; biotin: $200 \mathrm{mg}$ and inositol: $80,000 \mathrm{mg}$

${ }^{\mathrm{b}}$ Minerals mixture: calcium $=23 \mathrm{~g}$, Phosphore $=18 \mathrm{~g}$, magnesium $=0.21 \mathrm{~g}$, copper sulfate $=0.8 \mathrm{~g}$, cobalt sulfate $=0.02 \mathrm{~g}$, manganese sulfate $=0.6 \mathrm{~g}$, zinc sulfate $=8.15 \mathrm{~g}$, selenium sulfate $=0.04 \mathrm{~g}$, ferrous sulfate $=0.9 \mathrm{~g}$ 
to $5.6 \%$ of the total fish body weight as recommended by Hogendoorn (1983) during 56 days. All the fish of each tank were counted and weighed every 2 weeks and the feed amount was adjusted accordingly.

Chemical analysis

Proximate composition of feeds ingredient, diets and fish whole-body composition before and after the experiments were analyzed for crude protein, crude lipid, crude fiber, ash, moisture, and nitrogen-free extracts according to (AOAC 1990). Gross energy was calculated on the basis of $23.65 \mathrm{~kJ} / \mathrm{g}$ for protein, $40 \mathrm{~kJ} / \mathrm{g}$ for lipid and $16.8 \mathrm{~kJ} / \mathrm{g}$ for carbohydrate (Jobling 1983). For fatty acid analysis, total lipid was extracted from samples according to Folch et al. (1957). Fatty acid analysis was performed on each lipid sources, experimental diets and on muscles lipids of fish samples from each aquarium. Fatty acids profiles were analyzed according to Legrand et al. (2010) using a gas chromatograph (WATERS Agilent, model HP 6890N) coupled by mass spectrometer (Quattro micro GC, MICROMASS).

Growth performance, nutrient efficiency, biological and economical parameters

The growth performance, nutrient efficiency and biological indices were calculated using the following formulae:

$$
\text { Mean weight gain }(\mathrm{MWG})=\frac{\text { Final body weight }- \text { initial body weight }}{\text { Number of fish }}
$$

$$
\text { Survival rate }(\mathrm{SR}, \%)=100 \times \frac{\text { Final number }}{\text { Initial number }}
$$

Specific growth rate $($ SGR, $\% /$ day $)=100 \times \frac{\ln [\text { final body weight }(\mathrm{g})]-\ln [\text { initial body weight }(\mathrm{g})]}{\text { Number of experimental days }}$

$$
\begin{gathered}
\text { Feed conversion ratio }(\mathrm{FCR})=\frac{\text { Feed intake }(\mathrm{g})}{\text { Fish weight gain }(\mathrm{g})} \\
\text { Protein efficiency ratio }(\text { PER })=\frac{\text { Fish weight gain }(\mathrm{g})}{\text { Protein intake }(\mathrm{g})} \\
\text { Hepatosomatic index }\left(\text { HSI, \%) }=100 \times \frac{\text { Liver weight }(\mathrm{g})}{\text { Final weight }(\mathrm{g})}\right. \\
\text { Viscerosomatic index }(\text { VSI, } \%)=100 \times \frac{\text { Visceral weight }(\mathrm{g})}{\text { Final weight }(\mathrm{g})} .
\end{gathered}
$$

Economic evaluations in terms of gross profit (GP), net profit value (NPV), investment cost analysis (ICA), and benefit cost ratio of using tree oils in C. gariepinus juveniles production were determined according to Faturoti and Lawal (1986) and Mazid et al. (1997).

Net profit value $(\mathrm{NPV}, \$)=$ Final mean weight of fish cropped $\times$ Total number of the survival $\times$ Cost per $\mathrm{kg}$,

where $1 \mathrm{~kg}$ of fish costs $16.3 \$$,

Investment cost analysis (ICA, $\$)=$ Cost of feeding $(\$)+$ cost of fingerlings stocked, where $1 \mathrm{~g}$ of fingerling costs $0.016 \$$, 
Gross profit $(\mathrm{GP}, \$)=$ Net profit value $(\$)$ - Investment cost analysis $(\$)$

Benefit : cost ratio $(\mathrm{BCR})=\frac{\text { Total cost of fish cropped }(\$)}{\text { Investment cost analysis }(\$)}$.

Statistical analyses

Data were expressed as mean $\pm \mathrm{SD}(n=3)$. The effects of diet were tested with one way analysis of variance (ANOVA), followed by Tukey's test. Differences were considered significant when $P<0.05$. Statistical analyses were performed using STATISTICA 7.1 software.

\section{Results}

Fatty acids of lipids sources and experimental diets

The analyzed proximate composition of the trial diets (Table 1) was consistent with formulated values and was approximately similar in all treatments. The fatty acid composition of the experimental diets reflected the fatty acid composition of the lipid sources (Table 2). The dominant saturated fatty acid (SFA) in the three lipid sources and their corresponding diets was palmitic acid. This one was higher in D2 (28.62\%) and D3 presented the lowest $(16.84 \%)$. Oleic acid was the predominant monounsaturated fatty acid (MUFA) in trial diets with highest concentration observed in D3 (32.91), whereas the lowest in D1. Concerning polyunsaturated fatty acids (PUFA), linoleic acid was the highest n-6 fatty acid, while eicosapentaenoic acid (EPA) and

Table 2 Fatty acid composition (\% total fatty acids) of the different lipid sources and the experimental diets

\begin{tabular}{|c|c|c|c|c|c|c|}
\hline \multirow[t]{2}{*}{ Fatty acids } & \multicolumn{3}{|c|}{ Lipid sources } & \multicolumn{3}{|l|}{ Diets } \\
\hline & FO & $\mathrm{PO}$ & $\mathrm{CKO}$ & D1 & D2 & D3 \\
\hline $14: 00$ & 10.35 & 0.46 & 0.36 & 8.19 & 4.37 & 4.36 \\
\hline 16:00 & 25.64 & 42.16 & 11.45 & 22.17 & 28.62 & 16.84 \\
\hline 18:00 & 4.37 & 4.12 & 7.94 & 4.53 & 4.43 & 5.91 \\
\hline $20: 00$ & 0 & 0.26 & 0.19 & 0.04 & 0.14 & 0.12 \\
\hline$\Sigma$ SFA & 40.36 & 43 & 19.94 & 34.93 & 37.2 & 27.23 \\
\hline $16: 1 n-7$ & 14.47 & 0.06 & 0.24 & 8.96 & 3.43 & 3.5 \\
\hline $18: 1 n-9$ & 10.96 & 40.61 & 60.6 & 13.86 & 25.24 & 32.91 \\
\hline $18: 1 n-7$ & 2.92 & 0.97 & 0.13 & 2.02 & 1.27 & 0.94 \\
\hline $20: 1 n-9$ & 0.84 & 0.06 & 0 & 0.77 & 0.47 & 0.45 \\
\hline$\Sigma$ MUFA & 29.19 & 47.7 & 60.97 & 25.61 & 30.41 & 37.8 \\
\hline $18: 2 n-6$ & 1.34 & 9.06 & 16.94 & 10.73 & 13.69 & 16.72 \\
\hline $18: 3 n-6$ & 2.37 & 0 & 0 & 2.92 & 2.01 & 2.01 \\
\hline $20: 4 n-6$ & 1.2 & 0 & 0.5 & 1.16 & 0.84 & 1.03 \\
\hline$\Sigma \mathrm{n}-6$ & 4.91 & 9.06 & 17.44 & 14.91 & 16.54 & 19.76 \\
\hline $18: 3 n-3$ & 1.6 & 0 & 0.2 & 1.48 & 0.78 & 0.95 \\
\hline $20: 5 n-3$ (EPA) & 12.5 & 0 & 0 & 9.45 & 4.65 & 4.66 \\
\hline $22: 5 n-3$ & 1.27 & 0 & 0 & 1.74 & 1.26 & 1.25 \\
\hline $22: 6 n-3$ (DHA) & 8.15 & 0.02 & 0.03 & 6.67 & 3.54 & 3.55 \\
\hline$\Sigma \mathrm{n}-3$ & 23.52 & 0.02 & 0.23 & 19.34 & 10.23 & 10.41 \\
\hline$\Sigma$ PUFA & 28.43 & 9.08 & 17.97 & 34.25 & 26.86 & 30.17 \\
\hline$\sum n-3 / \Sigma n-6$ & 4.79 & 0.00 & 0.01 & 1.29 & 0.62 & 0.52 \\
\hline
\end{tabular}

FO fish oil, $P O$ palm oil, $C K O$ cashew kernel oil, SFA saturated fatty acids, MUFA monounsaturated fatty acids, PUFA polyunsaturated fatty acids, EPA eicosapentaenoic acid, DPA docosapentaenoic acid, DHA docosahexaenoic acid 
docosahexanoic acid (DHA) were the predominant n-3 fatty acid. Although palm oil (PO) and cashew kernel oil (CKO) contained few EPA and DHA, their corresponding diet contained high concentration of these fatty acids.

D3 contained the highest concentrations of n-6 PUFA with $16.72 \%$ in the form of linoleic acid. D1 contained the highest amounts of n-3 PUFA with $9.45 \%$ in the form of EPA and $6.67 \%$ as DHA. The concentration of EPA and DHA were identical in D2 and D3.

Growth performance, nutrient efficiency and biological indices

At the end of trial period, C. gariepinus fingerlings fed with D1 and D3 had significantly identical FMW, MWG SGR, feed intake, and PER. These parameters were higher in fish fed with D3 than those fed with D2 even though the difference was not significant (Table 3). FCR of fish fed in D1 was significantly identical with that of fish fed in D3 while was significantly higher than that of D2 fed fish. This nutrient utilization index was numerically higher in D3 fed fish than fish fed with D2. No significant survival rate difference was observed between fish batches fed with experimental diets. This parameter was around $91 \%$ for all treatments. Biological indices (HIS and VSI) did not show significant differences among fish fed with the trial diets (Table 3).

Economical parameters

The analyzed economical parameters are presented in Table 4. D1 was the most expensive diet while D3 was cheaper. ICA was significantly higher in fish fed with D1. NPV was higher with D1, followed by D3, and the lowest was obtained with D2. No significant difference was observed regarding GP for all treatments, but this parameter was numerically higher in fish fed with D3. BCR was significantly higher with D3 and D2, however, fish fed with D3 shown larger BCR than D2.

Whole-body proximate composition and muscle fatty acids of fish

The whole-body moisture, protein, lipid, and ash content of fish were not significantly affected by the dietary lipid sources (Table 5). However, whole-body proximate compositions of the African catfish of all treatments were higher than the initial body composition for all the parameters measured except the moisture. The fatty acid composition of the muscle lipids generally reflected those of the corresponding diets with a few exceptions (Table 6). However, a few minor differences between diets and muscle tissue of fish have been noticed. Contrary to PUFA and SFA, MUFA concentrations were generally high in the muscle lipids regardless of dietary treatments. Oleic acid (18:1n-9) was higher in muscle lipids compared to their corresponding diet. Linoleic acid (18:2n-6) and $\gamma$-Linolenic acid (18:3n-6) were higher in dietary lipids than in muscle tissues.

Table 3 Growth performance, nutrient efficiency and biological parameters of Clarias gariepinus fingerlings fed trial diets

\begin{tabular}{lcrc}
\hline Indices & \multicolumn{2}{l}{ Diets } & D3 \\
\cline { 2 - 4 } & \multicolumn{1}{c}{ D1 } & D2 & $2.39 \pm 0.29$ \\
\hline IMW (g) & $2.44 \pm 0.13$ & $2.46 \pm 0.35$ & $31.04 \pm 1.17^{\mathrm{ab}}$ \\
FMW (g) & $33.21 \pm 0.53^{\mathrm{a}}$ & $28.60 \pm 1.19^{\mathrm{b}}$ & $28,65 \pm 1.19^{\mathrm{ab}}$ \\
MWG (g) & $30.77 \pm 0.52^{\mathrm{a}}$ & $26.14 \pm 1.25^{\mathrm{b}}$ & $4.57 \pm 0.08^{\mathrm{ab}}$ \\
SGR (\%/day) & $4.66 \pm 0.03^{\mathrm{a}}$ & $4.38 \pm 0.11^{\mathrm{b}}$ & $37.78 \pm 1.27^{\mathrm{ab}}$ \\
Feed intake (mg) & $39.98 \pm 0.72^{\mathrm{a}}$ & $35.31 \pm 1.92^{\mathrm{b}}$ & $1.31 \pm 0.0^{\mathrm{ab}}$ \\
FCR & $1.29 \pm 0.00^{\mathrm{a}}$ & $1.35 \pm 0.03^{\mathrm{b}}$ & $1.55 \pm 0.01^{\mathrm{ab}}$ \\
PER & $1.57 \pm 0.00^{\mathrm{a}}$ & $1.51 \pm 0.03^{\mathrm{b}}$ & $91.33 \pm 3.05$ \\
SR (\%) & $90.66 \pm 2.3$ & $0.97 \pm 0.22$ & $1.03 \pm 0.14$ \\
HSI & $1.08 \pm 0.18$ & $2.03 \pm 0.16$ & $2.11 \pm 0.13$ \\
VSI & $2.09 \pm 0.26$ & \\
\hline
\end{tabular}

Data are mean values $\pm \mathrm{SD}(n=3)$; means in the same row with the same superscript were not significantly different $(P>0.05)$ 
Table 4 Economical parameters of Clarias gariepinus fingerlings fed with trial diets

\begin{tabular}{llll}
\hline Indices & Diets & & D3 \\
\cline { 2 - 4 } & D1 & D2 & 0.81 \\
\hline Cost of lipid source $(\$ / L)$ & 16.30 & 1.95 & 3.73 \\
Cost of feed $(\$ / \mathrm{kg})$ & 4.67 & 3.79 & $7.86 \pm 0.23^{\mathrm{b}}$ \\
ICA $(\$)$ & $10.14 \pm 0.16^{\mathrm{a}}$ & $7.50 \pm 0.36^{\mathrm{b}}$ & $23.15 \pm 1.11^{\mathrm{ab}}$ \\
NPV $(\$)$ & $24.59 \pm 0.41^{\mathrm{a}}$ & $21.51 \pm 1.67^{\mathrm{b}}$ & $15.29 \pm 0.95$ \\
GP $(\$)$ & $14.45 \pm 0.49$ & $14.01 \pm 1.31$ & $2.95 \pm 0.09^{\mathrm{b}}$ \\
BCR & $2.42 \pm 0.06^{\mathrm{a}}$ & $2.86 \pm 0.08^{\mathrm{b}}$ & \\
\hline
\end{tabular}

ICA, NPV, GP and BCR are expressed as mean values $\pm \mathrm{SD}(n=3)$; means in the same row with the same superscript were not significantly different $(P>0.05)$. Prices in $\$(\mathrm{USD}) ; 1 \$(\mathrm{USD})=613.20$ FCFA (UEMOA), based on conversion rate of November 16, 2016c

Table 5 Proximate whole-body composition (\% wet weight) of Clarias gariepinus fingerlings fed trial diets for 8 weeks

\begin{tabular}{lrrrr}
\hline & \multicolumn{1}{l}{ Initial } & \multicolumn{1}{c}{ D1 } & \multicolumn{1}{c}{ D2 } & \multicolumn{1}{c}{ D3 } \\
\hline Moisture (\%) & $73.56 \pm 0.22$ & $71.32 \pm 1.15$ & $72.00 \pm 0.77$ & $70.88 \pm 1.59$ \\
Protein (\%) & $15.32 \pm 0.04$ & $17.43 \pm 0.84$ & $16.89 \pm 0.56$ & $17.45 \pm 1.09$ \\
Lipid (\%) & $4.98 \pm 0.25$ & $7.27 \pm 0.25$ & $6.90 \pm 0.73$ & $7.61 \pm 0.69$ \\
Ash (\%) & $3.53 \pm 0.36$ & $3.98 \pm 0.41$ & $4.21 \pm 0.34$ & $4.06 \pm 0.19$
\end{tabular}

Data are mean values $\pm \mathrm{SD}(n=3)$; means in the same row with the same superscript were not significantly different $(P>0.05)$

Table 6 Muscle fatty acids composition (\% total fatty acids) of Clarias gariepinus fingerlings fed on trial diets for 8 weeks

\begin{tabular}{|c|c|c|c|c|}
\hline Fatty acids & Initial & D1 & $\mathrm{D} 2$ & D3 \\
\hline $14: 00$ & 3.92 & $6.94 \pm 1.11 \mathrm{a}$ & $3.75 \pm 0.21 b$ & $3.91 \pm 0.44 b$ \\
\hline $16: 00$ & 22 & $21.34 \pm 1.31^{\mathrm{a}}$ & $25.17 \pm 1.74^{\mathrm{a}}$ & $14.68 \pm 1.78^{b}$ \\
\hline 18:00 & 7.27 & $6.09 \pm 0.45$ & $6.16 \pm 0.24$ & $6.96 \pm 0.31$ \\
\hline$\Sigma$ SFA & 33.19 & 34.37 & 35.08 & 25.55 \\
\hline $16: 1 n-7$ & 3.64 & $7.71 \pm 0.36^{\mathrm{a}}$ & $3.20 \pm 0.14^{\mathrm{b}}$ & $3.46 \pm 0.25^{\mathrm{b}}$ \\
\hline $18: 1 n-9$ & 25.04 & $20.55 \pm 2.21^{\mathrm{a}}$ & $35.13 \pm 3.62^{\mathrm{b}}$ & $43.85 \pm 2.33^{c}$ \\
\hline $18: 1 n-7$ & 0.31 & $0.21 \pm 0.04$ & $0.11 \pm 0.04$ & $0.11 \pm 0.08$ \\
\hline $20: 1 n-9$ & 1.89 & $0.12 \pm 0.09$ & $0.15 \pm 0.06$ & $0.05 \pm 0.05$ \\
\hline$\Sigma$ MUFA & 30.88 & 28.59 & 38.59 & 47.47 \\
\hline $18: 2 n-6$ & 11.71 & $11.65 \pm 1.18^{\mathrm{a}}$ & $13.29 \pm 0.69^{\mathrm{a}}$ & $15.57 \pm 0.59^{b}$ \\
\hline $18: 3 n-6$ & 0.46 & $0.41 \pm 0.22$ & $0.2 \pm 0.08$ & $0.27 \pm 0.10$ \\
\hline $20: 2 n-6$ & 0.18 & $0.74 \pm 0.53$ & $0.25 \pm 0.15$ & $0.21 \pm 0.09$ \\
\hline $20: 3 n-6$ & 0.68 & $1.49 \pm 0.74$ & $0.97 \pm 0.23$ & $1.03 \pm 0.65$ \\
\hline $20: 4 n-6$ & 0.81 & $0.87 \pm 0.23$ & $0.74 \pm 0.19$ & $0.79 \pm 0.26$ \\
\hline$\Sigma \mathrm{n}-6$ & 13.84 & 15.16 & 15.45 & 17.87 \\
\hline $18: 3 n-3$ & 1.98 & $1.92 \pm 0.61$ & $1.09 \pm 0.39$ & $1.13 \pm 0.32$ \\
\hline $20: 5 n-3(\mathrm{EPA})$ & 2.19 & $5.54 \pm 0.69$ & $2.27 \pm 0.41^{\mathrm{b}}$ & $2.04 \pm 0.66^{\mathrm{b}}$ \\
\hline $22: 5 n-3$ & 0.99 & $1.37 \pm 51^{\mathrm{a}}$ & $0.88 \pm 0.8^{\mathrm{b}}$ & $0.94 \pm 0.11^{\mathrm{b}}$ \\
\hline 22:6n-3 (DHA) & 3.58 & $5.86 \pm 1.94^{\mathrm{a}}$ & $3.24 \pm 1.01^{\mathrm{b}}$ & $2.84 \pm 0.88^{b}$ \\
\hline$\Sigma \mathrm{n}-3$ & 8.74 & 16.69 & 7.48 & 6.95 \\
\hline$\Sigma$ PUFA & 22.5 & 31.85 & 22.93 & 24.82 \\
\hline
\end{tabular}

Data are mean values $\pm \mathrm{SD}(n=3)$; means in the same row with the same superscript were not significantly different $(P>0.05)$. SFA saturated acids, MUFA monounsaturated acids, PUFA polyunsaturated acids, EPA eicosapentaenoic acid, DPA docosapentaenoic acid, DHA docosahexaenoic acid 
Dihomo- $\gamma$-linolenic acid (20:3n-6) and eicosadienoic acid (20:2n-6) were absent in diets, while they were present in whole-body lipids. EPA concentrations were generally lower in muscle lipids than in the dietary fats.

\section{Discussion}

The results of this present study show that fingerlings of $C$. gariepinus responded well to all the experimental diets, since fish of all groups displayed high survival rate (around to 91\%) and rapid growth with SGR ranged from 4.38 to $4.66 \% /$ day. Nevertheless, African catfish fed with diets containing CKO (high in 18:2n-6) and FO (high in EPA and DHA) exhibited higher weight gain and feed utilization efficiency compared to fish fed with diets containing PO. Besides, fish fed with CKO and FO did not show significant difference in growth. Similar results have been obtained by previous studies showing significant similar growth performance in African catfish fed with vegetable oils and fish oil diets (Legendre et al. 1995; Lim et al. 2001; Sotolu 2010). However, $\mathrm{Ng}$ et al. (2003) obtained lower growth performance in African catfish fed with diets containing fish oil as compared to fish fed with diets supplemented with various vegetable oils (sunflower oil, crude palm kernel oil, crude palm oil). This difference is probably due to the fatty acids contents of the FO used. Indeed, $\mathrm{Ng}$ et al. (2003) used cod liver oil (very low in n-6 PUFA and high n-3/n-6), while menhaden oil (low n-6 PUFA and low $n-3 / n-6$ ) has been used in the present study. A minimum level of $0.5-1 \%$ dietary $n-3$ fatty acids has been recommended for Heterobranchus longifilis fry (Kerdchuen 1992). In this study trial, diets n-3 fatty acids which ranged from 10.23 to $19.34 \%$ of total fatty acids (1.62-2.92\% of dry feed) met the reference values recommended for African catfish Heterobranchus longifilis. Contrary to $\mathrm{Ng}$ et al. (2003) who observed growth decreasing in C. gariepinus fed high concentration of n-3 fatty acids, D1 containing the highest concentration of n-3 fatty acids allowed the best growth performance. However, Satoh et al. (1989) showed that n-3 highly unsaturated fatty acids appear to be responsible for the enhanced growth of Channel Catfish (Ictalurus punctatus). Besides, n-3 lowering in trout diets reduced the animals' resistance to the IHN virus (Kiron et al. 1995). Thus, growth decreasing of fish fed with D2 might not be associated to the dietary n-3 concentration, since the concentrations of n-3 fatty acids were identical in D2 and D3. However, the n-3 fatty acids of these diets were around $10 \%$ of total fatty acids or $1.5 \%$ of diets. This value met the $C$. gariepinus $\mathrm{n}-3$ fatty acid requirement which was ranged from 0.5 to $0.75 \%$ of the ration (Corraze 1999). The relative high concentration of n-3 including EPA and DHA in PO and CKO diets was originated to the residual oil found in fishmeal. Fish eating a diet containing CKO displayed a higher growth than those fed with PO diet despite those diets contained the same amount of DHA and EPA. The decreasing of weight gain and feed utilization efficiency in fish fed with D2 could be due the low concentration of $\mathrm{n}-6$ fatty acids in this diet (16.54\%) compared to D3 $(19.76 \%)$. This finding is consistent with previous study showing best growth of African catfish fed with sunflower oil (high in 18:2n-6) diet ( $\mathrm{Ng}$ et al. 2003). In the other hand, D1 and D3 contained higher concentration of linolenic (18:3n-3) acid than D2. Linoleic (18:2n-6) and linolenic acids (18:3n-3) are the main essential fatty acids for freshwater fish (Corraze 1999). Fish are unable to synthesize these fatty acids de novo. Therefore, fish must obtain these fatty acids via feed (Takeuchi et al. 1980). Besides, the higher amount of oleic acid (18:1n-9) in D3 than in D2 might be another raison that fish fed with D3 performed better than those fed with D2. This was in agreement with Stickney and Andrews (1972) who reported that channel catfish fed diets containing beef tallow (high in 18:ln-9 and low in 18:2n-6 and 18:3n-3) grew better.

Organ indices have been used as indicators of change in nutritional and energy status of fish (Adams et al. 1996). In the present study, fish biological indices (HIS and VSI) were not significantly affected by dietary lipid source. The same result was previously found by Mourente et al. (2005) in European sea bass fed with various vegetable oils. Our results were not in the same line with Ochang (2011) who reported higher HSI and lower VSI in Oreochromis niloticus fed with soybean oil than those fed with cod liver oil. This result suggests that lipid was deposited in the liver and perivisceral adipose tissue of fish of all treatments at a relatively uniform concentration, since these organs are the main fat-stocking sites in fish (Corraze 1999). Beyond, the identical organism indices in all treatments may indicate that fish health was not affected by lipid source, since these indices were used for assessing fish health (Goede and Barton 1990).

The whole-body proximate composition was not affected by the dietary lipid sources since trial diets had identical protein $(49.32 \pm 0.32 \%)$, lipid $(15.08 \pm 0.15 \%)$, NFE $(19.76 \pm 0.32 \%)$, and ash $(12.17 \pm 0.18 \%)$ 
contents. The fatty acids profile is important to assess the nutritional quality of the fish since this profile must generate maximum desirable fatty acids such as n-3 fatty acid, especially EPA and DHA which have important roles in human health. In the present study, muscle lipid fatty acids composition of fish was influenced by the fatty acid profile of the dietary lipid sources. This observation had also been reported in previous studies (Yingst and Stickney 1979; Bell et al. 2002; Ng et al. 2000, 2003). PUFA decreasing in muscle lipids was consecutive to EPA, DHA, linoleic, and $\gamma$-Linolenic acids lowering. Specially, the lowering of EPA in fish fed with diets D2 and D3 indicates the decreasing of this fatty acid retention when the fish were fed with plant oil. This is on the same line with $\mathrm{Ng}$ et al. (2003) who reported that feeding fish with vegetable oils decreased the muscle content of EPA, DHA and ARA. The MUFA increasing in muscle tissue resulting in oleic acid raising may suggest that $C$. gariepinus have high activity of $\Delta 9$-desaturases enzymes which allows the bioconversion of SFA (16:0 and 18:0) to oleic acid. Moreover, stearic and palmitic acids can be biosynthesized de novo by all known organisms, including fish, by the conventional pathway (Sargent et al. 2002). 18:2n-6 and 18:3n-3 are essential fatty acid for many animals including many species of freshwater fish. These essentials fatty acid can be desaturated further and elongated to form the physiologically essential $C_{20}(20: 4 n-6 ; 20: 5 n-3)$ and $C_{22}$ (22:6n-3) PUFA. Desaturation and elongation dependent on the relative activities of fatty acid elongases and desaturases such as $\Delta 5$ and $\Delta 6$ in animals (Tocher 2003). An absence of either of these fatty acids in the diet has been showed leads to the desaturation and chain elongation of oleic acid, 18:1n-9, to 20:3n-9, which is characteristic of an EFA deficiency in many terrestrial animals (NRC 1993). Thus, when EFA are deficient, increased concentrations of 20:3n-9 are incorporated into tissue lipids in place of 20:4n-6, 20:5n-3, or 22:6n-3. The absence of 20:3n-9 and the relative high concentrations of 20:4n-6, 20:5n-3 and 22:6n-3 in the tissue of $C$. gariepinus observed in this study showed that the dietary EFA requirements are met. The appearance of 20:3n6 and 20:2n-6 might, respectively, be due to the bioconversion of 18:3n-6 and 18:2n-6 (Bell et al. 1986). The lowering of linolenic acid in fish muscle lipids compared to initial might be due to the low amounts of this fatty acid in trial diets. Indeed, the fatty acids of muscle lipids in African catfish reflected the fatty acid profile of the dietary oil that was fed (Ng et al. 2003; Babalola et al. 2011).

The best growth performance allowed to obtain the highest NPV in fish fed with D1, while the high price $(16.30 \$ / \mathrm{L})$ of fish oil used in this diet caused the decreasing of the GP observed in this group. However, highest GP and BCR resulting of the cheaper cost of cashew kernel oil $(0.81 \$ / \mathrm{L})$ were recorded with D3. As regards, palm oil, GP, and BCR were numerically lower than fish fed with cashew kernel oil due to its relative high cost $(1.95 \$ / \mathrm{L})$.

This study showed that expensive fish oil can be replaced by cashew kernel oil in C. gariepinus diet without negatively affecting growth performance. So, this lipid source might be recommended in order to reduce fish production cost. However, inclusion of cashew kernel oil in the diet of $C$. gariepinus produced tissue with low concentrations of long chain n-3 PUFA. Nevertheless, it would be interesting to analyze the effects of incorporating this oil in C. gariepinus practical diets formulated with unconventional protein source.

Acknowledgements This work was funded by the project "Tilapia's seed improvement-UEMOA-UPB" and by the project HAAGRIM through its mobility scholarships (First cohort). The authors are grateful to Mr. Dibi Koffi Sylvain for biochemical analyses, to Silga Touwendsida Eric and Kagambega Florence for their technical assistances during the experiment.

Open Access This article is distributed under the terms of the Creative Commons Attribution 4.0 International License (http:// creativecommons.org/licenses/by/4.0/), which permits unrestricted use, distribution, and reproduction in any medium, provided you give appropriate credit to the original author(s) and the source, provide a link to the Creative Commons license, and indicate if changes were made.

\section{References}

Adams SM, Ham KD, Greeley MS, LeHew RF, Hinton DE, Saylor CF (1996) Downstream gradients in bioindicator responses: point source contaminant effects on fish health. Can J Fish Aquat Sci 53:2177-2187

Aderolu AZ, Akinremi OA (2009) Dietary effects of coconut oil and peanut oil in improving biochemical characteristics of Clarias gariepinus juvenile. Turk J Fish Aquat Sci 9:105-110

Aderolu AZ, Bello R, Aarode OO, Sanni RO (2011) Utilization of two dietary plant oil sources on growth, haematology, histometry and carcass analysis of juvenile Clarias gariepinus. PAT 7(1):117-130

AOAC (1990) Official methods of analysis, 15th edn. Association of Official Analytical Chemists, Arlington, p 1298 
Babalola TOO (2010) Utilization of dietary animal fats and vegetable oils by African catfish (Heterobranchus longifilis) fingerlings. Ph.D. Thesis University of Ilorin, Nigeria

Babalola TO, Apata DF, Omotosho JS, Adebayo MA (2011) Differential effects of dietary lipids on growth performance, digestibility, fatty acid composition and histology of African catfish (heterobranchus longifilis) fingerlings. FNS 2:11-21

Barlow S (2000) Fishmeal and fish oil: sustainable feed ingredients for aquafeeds. Glob Aquac Advocate 4:85-88

Bell MV, Henderson RJ, Sargent JR (1986) The role of polyunsaturated fatty acids in fish. Comp Biochem Physiol 83B:711-719

Bell JG, Henderson RJ, Tocher DR, McGhee F, Dick JR, Porter A, Smullen RP, Sargent JR (2002) Substituting fish oil with crude palm oil in the diet of Atlantic salmon (Salmo salar) affects muscle fatty acid composition and hepatic fatty acid metabolism. J Nutr 132:222-230

Bila KB, Djibo OPC, Sanon B (2010) Analysis of the cashew value chain in Burkina Faso. Deutsche Gesellschaft für Internationale Zusammenarbeit (GIZ)-African Cashew initiative (ACi), Burkina Faso, pp 40

Corraze G (1999) Nutrition lipidique. In: Guillaume J, Kaushik S, Bergot P, Métailler R (eds) Nutrition et alimentation des poissons et crustacés. INRA, Paris, pp 147-170

Effiong MU, Akpan AW (2016) Evaluation of the biochemical responses of catfish (clarias gariepinus burchell, 1822) after replacing fish oil with plant-based oils in their diets. J Appl Sci Environ Manage 20(4):1069-1073

Fagbenro OA, Arowosegbe IA (1991) Utilization of agricultural wastes and byproducts in fish feeds production in Nigeria. In: Proceedings of 6th Annual FISON Conference, Lagos, pp 121-130

FAO (2016) La situation mondiale des pêches et de l'aquaculture 2016. Contribuer à la sécurité alimentaire et à la nutrition de tous, Rome, p 224

Faturoti EO, Lawal LA (1986) Performance of supplementary feeding and organic manuaring on the production of Oreochromis niloticus. J West Afr Fish 1:25-32

Folch J, Lees M, Stanley GHS (1957) A simple method for the isolation and purification of total lipids from animal tissues. J Biol Chem 226:497-509

Goede RW, Barton BA (1990) Organismic indices and an autopsy-based assessment as indicators of health and condition of fish. Am Fish Soc Symp 8:93-108

Hammed AM, Amosu AO, Fashina-Bombata HA, Ajepe RG, Olufowobi MT (2014) The use of coconut (Cocos nucifera) oil as an alternative source of energy in the diets of African Mudcatfish (Clarias gariepinus-Burchell, 1822) juveniles. IJSE R 5(8):431-436

Hecht T, Oellermann L, Verheust L (1996) Perspectives on clariid catfish culture in Africa. Aquat Living Resour 9:197-206

Hogendoorn H (1983) Growth and production of the African catfish, Clarias lazera (C. \& V.): III. Bioenergetic relations of body weight and feeding level. Aquaculture 35:1-17

Idah P, Simeon M, Mohammed M (2014) Extraction and characterization of cashew nut (Anacardium occidentale) oil and cashew shell liquid oil. Acad Res Int 5(3):50-54

Jobling M (1983) A short review and critique of methodology used in fish growth and nutrition studies. J Fish Biol 23:686-703

Kabré TA, Sanogo S, Naba M (2014) Aquaculture en zone sahélo-soudanienne: diagnostic des réalisations et analyse d'impact socioéconomique de la filière poisson au Burkina Faso. J Appl Biosci 76:6368-6385

Kerdchuen N (1992) L'alimentation artificielle d'un silure africain, Heterobranchus longifilis (Teleostei. Clariidae): Incidence du mode d'alimentation et première estimation des besoins nutritionnels. Thesis, University of Paris-VI, p 182

Kiron V, Fukuda H, Takeuchi T, Watanabe T (1995) Essential fatty acid nutrition and defense mechanism in rainbow trout Oncorrynhus mykiss. Comp Biochem Physiol 111A:361-367

Legendre M, Kerdchuan N, Corraze G, Bergot P (1995) Larval rearing of an African catfish Heterobranchus longifilis (Teleostei, Clariidae): effect of dietary lipids on growth, survival and fatty acid composition of fry. Aquat Living Resour 8:355-363

Legrand P, Beauchamp E, Catheline D, Pédrono F, Rioux V (2010) Short chain saturated fatty acids decrease circulating cholesterol and increase tissue PUFA content in the rat. Lipids 45:975-986

Lim PK, Boey PL, Ng WK (2001) Dietary palm oil level affects growth performance, protein retention and tissue vitamin E concentration of African Catfish, Clarias gariepinus. Aquaculture 202(1-2):101-112

Mazid MA, Zaher M, Begum NN, Aliu MZ, Nahar F (1997) Formulation of cost-effective feeds from locally available ingredients for carp polyculture system for increase production. Aquaculture 151:71-78

Montero D, Grasso V, Izquierdo MS, Ganga R, Real F, Tort L, Caballero MJ, Acosta F (2007) Total substitution of fish oil by vegetable oils in gilthead sea bream (Sparus aurata) diets: effects on hepatic Mx expression and some immune parameters. Fish Shellfish Immunol 24:147-155

Mourente G, Good JE, Bell JG (2005) Partial substitution of fish oil with rapeseed, linseed and olive oils in diets for European sea bass (Dicentrarchus labrax L.): effects on flesh fatty acid composition, plasma prostaglandins E2 and F2a, immune function and effectiveness of a fish oil finishing diet. Aquac Nutr 11:25-40

Ng WK, Chong CY (2004) An overview of lipid nutrition with emphasis on alternative lipid sources in tilapia feeds. In: Bolivar RG, Mair GC, Fitzsimmons K (eds) Proceedings of the Sixth International Symposium on Tilapia in Aquaculture. Bureau of Fisheries and Aquatic Resources, Manila, pp 241-248

$\mathrm{Ng}$ WK, Tee MC, Boey PL (2000) Evaluation of crude palm oil and refined palm olein as dietary lipids in pelleted feeds for a tropical bagrid catfish Mystus nemurus (Cuvier and Valenciennes). Aquac Res 31:337-347

Ng WK, Lim PK, Boey PL (2003) Dietary lipid and palm oil source affects growth, fatty acid composition and muscle $\alpha$ tocopherol concentration of African catfish, Clarias gariepinus. Aquaculture 215:229-243

NRC (1993) Nutrient requirements of fish. National Academy Press, Washington, DC, p 105

Nyina-wamwiza L, Wathelet B, Kestemont P (2007) Potential of local agricultural by-products for the rearing of African catfish, Clarias gariepinus in Rwanda: effects on growth, feed utilization and body composition. Aquac Res 38:206-214

Ochang SN (2011) Effect of replacing cod liver oil with soybean oil as dietary lipid on carcass composition, haematology and sensory properties of the Nile tilapia Oreochromis niloticus. Int Aquat Res 3:71-77 
Potts WM, Hecht T, Andrew TG (2008) Does reservoir trophic status influence the feeding and growth of the sharptooth catfish, Clarias gariepinus (Teleostei: Clariidae)? Afr J Aquat Sci 33:149-156

Rabany C, Rullier N, Ricau P (2015) Analysis of cashew production, processing and trade in Africa. RONGEAD/ICA p 37

Riediger ND, Othman RA, Suh M, Moghadasian MH (2009) A systemic review of the roles of n-3 fatty acids in health and disease. J Am Diet Assoc 109(4):668-679

Sargent JR, Tocher DR, Bell JG (2002) The lipids. In: Halver JE, Hardy RW (eds) Fish nutrition, 3rd edn. Elsevier, USA, pp 181-257

Satoh S, Poe WE, Wilson RP (1989) Studies on the essential fatty acid requirement of channel catfish, Ictalurus punctatus. Aquaculture 79:121-128

Sotolu AO (2010) Feed utilization and biochemical characteristics of Clarias gariepinus (Burchell, 1822) Fingerlings fed diets containing fish oil and vegetable oils as total replacements. World J Fish Mar Sci 2(2):93-98

Stickney RR, Andrews JW (1972) Effects of dietary lipids on growth, food conversion, lipid and fatty acid composition of channel catfish. J Nutr 102:249-258

Takeuchi T, Arai S, Watanabe T, Shimma Y (1980) Requirement of eel anguilla japonica for essential fatty acids. Bull Jpn Soc Sci Fish 46(3):345-353

Tocher DR (2003) Metabolism and functions of lipids and fatty acids in teleost fish. Rev Fish Sci 11(2):107-184

Yilmaz E, Naz M, Akyurt I (2004) Effect of dietary olive pomace oil and Lcarnitine on growth and chemical composition of African catfish, (Burchell, 1822). Isr J Aquac Bamidgeh 56(1):14-21

Yingst WL, Stickney RR (1979) Effects of dietary lipids on fatty acid composition on channel catfish fry. Trans Am Fish Soc 108:620-625 